\title{
Relationship Between Fat and Ketone Body Metabolism in Obese and Nonobese Diabetics and Nondiabetics During Norepinephrine Infusion*
}

\author{
B. Wrums, M. Bötтcher, V. Wolteks, N. SAKayoto, and H..-D. SöLING \\ Medizinische Universitätsklinik Göttingen
}

Received: June 19, 1968

\begin{abstract}
Summary. The effects of an intravenous infusion of norepinephrine, $0.08 \mu \mathrm{g} / \mathrm{kg} . \mathrm{min}$ on lipolysis (as measured by an increase of free glycerol and nonesterified fatty acids (NEFA), , on the blood concentration of ketone bodies and on the serum concentrations of immunoreactive insulin (IRI) and insulin-like activity (ILA) were studied in normal weight and obese nondiabetics and diabetics. Normal weight diabetics and nondiabetics showed the same increase in lipolysis. A significantly higher rate of lipolysis occurred in obese persons, irrespective of whether they were diabetic or not. Even the maximum absolute concentrations of free glycerol and NEFA during the infusion were higher in obese persons than in insulindependent diabetics, who showed the highest values before the beginning of the infusion. - In obese subjects, the infusion of norepinephrine according to the theoretical normal weight was still sufficient to produce a higher rate of lipolysis than in normal weight subjects. This probably reflects the greater mass of adipose tissue in obese subjects. - In diabetic and nondiabetic obese persons, the concentration of ketone bodies rose higher than in control subjects, which is in agreement with the higher rate of lipolysis in the obese groups. On the other hand, the normal weight insulin-dependent diabetics showed a significantly higher increase in the concentration of ketone bodies than the obese persons. This demonstrates that the degree of ketonaemia in man is not exclusively determined by the plasma level of NEFA. - The higher increase in the $\beta$-hydroxybutyrate/acetoacetate ratio in insulindependent diabetics points to a higher rate of oxidation of fatty acids in the liver. - ILA and IRI responded in a different way to norepinephrine infusion, demonstrating again, that changes in ILA can, but may not always reflect changes in immunoreactive insulin. According to these results, changes in the rate of lipolysis and in ketonaemia in obese diabetics are determined by the factor "obesity", whereas changes in these parameters in insulindependent diabetics are determined by the factor "insulin deficiency".
\end{abstract}

Relations entre le métabolisme de la graisse et des corps cétoniques chez des sujets normaux, obèses et diabétiques sous l'influence de la noradrénaline

Résumé. Les actions de la noradrénaline infusée par voie intraveineuse à une dose de $0.08 \mu \mathrm{g} / \mathrm{kg} / \mathrm{min}$ ont été explorées chez des sujets obèses et de poids normal, diabétiques et non diabétiques. Les paramètres suivants ont été étudiés: La lipolyse, mesurée par l'accroissement du glycérol libre et des acides gras plasmatiques non estérifiés (NEFA), l'élévation de la concentration sanguine des corps cétoniques et les concentrations plasmatiques de l'insuline immunoréactive (IRI) et de l'activité insulinique (ILA). Les sujets de poids normal, diabétiques et non diabétiques ont montré le même accroissement de la lipolyse. - Un accroissement do la lipolyse significativement plus

* A part of this work has been presented at the "12. Symposion der Deutschen Gesellschaft für Endokrinologie, Wiesbaden, Deutschland, 21.-23. 4. 1966". élevé a été observé chez des sujets obèses, diabétiques et non diabétiques. Même pendant l'infusion les concentrations absolues du glycérol libre et des NEFA ont été plus élevées chez les sujets obèses que chez les diabétiquos insulino-dépendants qui présentèrent les valeurs de départ les plus hautes. Les sujets obèses ont eu une lipolyse plus grande même lorsque la noradrénaline a été infusée à une dose proportionnelle au poids normal théorique. La cause en est probablement la plus grande quantité de tissu adipeux des sujets obèses. - Chez les obèses diabétiques et non-diabétiques, la concentration des corps cétoniques était plus élevée que chez les sujets de contrôle, ce qui est en accord avec la lipolyse augmentée chez les obèses. Les diabétiques de poids normal insulino-dépendants ont présenté cependant une élévation des corps cétoniques significativement plus forte que les obèses. - Ceci indique que chez l'homme la cétonémie ne dépend pas seulement des acides gras plasmatiques non estérifiés (NEFA). L'accroissement plus fort du quotient $\beta$-hydroxybutyrate/ acétoacétate chez les diabétiques insulino-dépendants suggère une oxydation plus grande des NEFA dans le foie. ILA et IRI ont réagi d'une manière différente à la noradrénaline. Ceci démontre de nouveau qu'un changement d'ILA peut indiquer un changement d'TRI, mais pas nécessairement. - Ces données suggèrent que le métabolisme des acides gras et des corps cétoniques du diabétique obèse est déterminé par l'élément «obésité», celui du diabétique dépendant de l'insuline par l'élément amanque d'insuline".

Beziehungen zwischen Fett- und Ketonkörperstoffwechsel bei übergewichtigen und normalgewichtigen Diabetikern und Nichtdiabetikern unter dem Einfluß von NoradrenalinInfusionen

Zusammenfassung. Die Wirkung einer intravenösen Infusion von $0.08 \mu \mathrm{g} / \mathrm{kg} / \mathrm{min}$ Noradrenalin auf die Lipolyse (gomessen am Anstieg des freien Glycerins und der unveresterten Fettsäuren (NEFA)), auf die Ketonkörperkonzentration im Blut und die Serumkonzentration des immunreaktiven Insulins (IRI) und der insulinähnlichen Aktivität (ILA) wurden bei normalgewichtigen und übergewichtigen Diabetikern und Nichtdiabetikern untersucht. - Normalgewichtige Diabetiker und Nichtdiabetiker zeigten die gleiche Lipolysesteigerung. Eine signifikant stärkere Lipolysesteigerung wurde bei den übergewichtigen Gruppen, sowohl bei Diabetikern, als auch bei Nichtdiabetikern, beobachtet. - Auch die absoluten Konzentrationen von freiem Glycerin und NEFA waren bei den fettsüchtigen Personen während der Infusion höher als bei den Insulinmangeldiabetikern, die die höchsten Ausgangswerte aufwiesen. Bei Fettsüchtigen wurde eine stärkere Lipolyse auch beobachtet, wenn Noradrenalin, auf $\mathrm{kg}$ theoretisches Normalgewicht dosiert, infundiert wurde. Als Ursache wird die größere Fettgewebsmasse der Adipösen angesehen. Bei fettsüchtigen Diabetikern und Nichtdiabetikern stieg die Ketonkörperkonzentration entspreehend der stärkeren Lipolyse stärker an als bei den Kontrollen. Die normalgewichtigen Insulinmangeldiabetiker zeigten jedoch einen signifikant höheren Ketonkör- 
peranstieg als die Fettsüchtigen. Dies zeigt, daß beim Menschen die Ketonämie nicht allein von den peripheren NEFA-Spiegeln abhängt. Der höhere Anstieg des $\beta$ Hydroxybutyrat/Acetoacetat Quotienten der Insulinmangeldiabetiker weist auf eine gesteigerte Fettsäureoxydation in der Leber hin. - ILA und IRI reagierten auf Noradrenalin in unterschiedlicher. Weise. Dadurch wird wiederum demonstriert, daß ILA-Änderungen Änderungen der IRI bedeuten können, aber nicht müssen. Nach den vorliegenden Untersuchungen scheint für den
Fettsäure- und Ketonkörperstoffwechsel des Altersdiabetes der Faktor Übergewicht, für den des normalgewichtigen Insulinmangeldiabetikers der Faktor Insulinmangel bestimmend zu sein.

Key-words. Norepinephrine infusion, NEFA, free glycerol, lipolysis, NEFA/glycerol ratio, blood glucose, ketone body metabolism, obesity, diabetes, $\beta$-hydroxybutyrate/ acetoacetate ratio, insulin-like activity, immunoreactive insulin.

\section{Introduction}

In experiments with isolated perfused livers of alloxan-diabetic rats, which were infused intraportally with non-esterified fatty acids (NEFA), Scow and Chernick [30] as well as Söling et al. [35, 36] did not find differences in ketogenesis compared with livers of nondiabetic animals. Insulin in vitro had no effect on ketogenesis of either normal or diabetic livers. According to these experiments, the hepatic formation of ketone bodies depends only on the supply of fatty acids to the liver. On the other hand, no direct correlation between the concentrations of NEFA and ketone bodies could be found in vivo. In children KAYE and DAVIDSON [17] saw a greater increase of ketone bodies than of NEFA after treatment with adrenaline and after fasting. WERK and KNowLES [41] observed higher blood levels of ketone bodies in diabetics than in nondiabetics at the same NEFA concentrations during a fat meal regimen. BLACKARD and OMORI [4] increased the concentrations of NEFA in normal weight and over-

\section{Methods}

The clinical data of the 5 groups studied are given in Table 1. The control subjects (C) were apparently normal, healthy ambulatory or hospitalized men or women. All were within $15 \%$ of their normal weight as calculated from the statistical tables of the Society of Actuaries [32]. None of them showed signs of impaired carbohydrate tolerance when tested with a standard $100 \mathrm{~g}$ oral glucose tolerance test, or had a near relative known to be diabetic. Patients with diseases of the liver, pancreatitis, alcoholism, nephrosis, gout or any endocrine disorder were excluded from these studies.

The insulin-dependent diabetic subjects (DI) were defined by the following criteria: insulin dependency and sensitivity, ineffectiveness of sulphonylurea drugs, proneness to ketosis, decreased serum level of immunoreactive insulin, normal or subnormal weight. The last criterion of this group - early manifestation of the disease - was lacking in one patient. This one was

Table 1. Number, age, and percentage of normal weight in the groups studied

\begin{tabular}{|c|c|c|c|c|}
\hline Group & Symbol & $\begin{array}{l}\text { Number } \\
\text { of } \\
\text { patients }\end{array}$ & $\begin{array}{l}\text { Age } \\
\text { (mean values } \\
\text { and range) }\end{array}$ & $\begin{array}{l}\text { Percentage of normal } \\
\text { weight } \\
\text { (mean values } \perp \text { s.d.) }\end{array}$ \\
\hline control group & $\mathrm{C}$ & 11 & $31(23-70)$ & $95 \pm 16$ \\
\hline $\begin{array}{l}\text { insulin-dependent } \\
\text { diabetic group }\end{array}$ & DI & 7 & $27(17-64)$ & $96 \pm 10$ \\
\hline $\begin{array}{l}\text { obese, insulin. } \\
\text { independent } \\
\text { diabetic group }\end{array}$ & $\mathrm{ObD}$ & 8 & $52(35-73)$ & $141 \pm 23$ \\
\hline $\begin{array}{l}\text { nonobese, insulin- } \\
\text { independent diabetic } \\
\text { group }\end{array}$ & NobD & 5 & $60(35-77)$ & $89 \pm 7$ \\
\hline $\begin{array}{l}\text { obese nondiabetic } \\
\text { group }\end{array}$ & $\mathrm{Ob}$ & 9 & $31(17-53)$ & $178 \pm 33$ \\
\hline
\end{tabular}

weight diabetic subjects by norepinephrine and found that the increase in the concentration of ketone bodies was more correlated to the degree of obesity and the range of fasting blood sugar than to the level of NEFA concentration. Because of the discrepancy between results in vitro and in vivo, we investigated the correlation between experimentally-induced lipolysis and blood ketone levels in normal weight and obese diabetics and nondiabetics. Furthermore, we tried to discriminate the fastor diabetes from the factor obesity.
64 years old and had suffered from diabetes for 17 years. The age of the remaining 6 patients ranged from 17 to 37 years. Two patients with recently discovered diabetes were untreated at the time of the experiment; insulin therapy started the day after the infusion. The known history of the others reached from 5 to 18 years. The daily insulin dose averaged 55 units. The last dose of insulin was given $24 \mathrm{~h}$ before the infusion experiment. Obese, insulin-independent diabetics (ObD) were characterized by an overweight of more than $30 \%$, lack 
of ketosis, sensitivity to sulphonylurea drugs in most cases, normal or elevated serum insulin levels, manifestation of the disease after the age of 40 . Four of these patients were only on dietary treatment, two were treated with tolbutamide, one with biguanides and one simultaneously with tolbutamide and biguanides. Oral drugs were withdrawn three days before the experiment. Normal weight, non-ketotic diabetics (NobD) were of the maturity-onset type. They had never been obese. Two of them were treated with tolbutamide, one with diet alone. Two of them used insulin. Fasting values of ketone bodies in the blood were low, and did not significantly differ from the values of the control group. Ketonuria was completely absent.

The obese nondiabetic subjects (Ob) were more than $30 \%$ overweight. An endocrine origin of the obesity had been excluded.

All patients were tested with the standard oral glucose tolerance test. Three had maximum values exceeding $160 \mathrm{mg} \%(198,196,208 \mathrm{mg} \%)$, two had 2 -h values above $120 \mathrm{mg} \%(140,164 \mathrm{mg} \%)$ but showed values below the fasting values after $3 \mathrm{~h}$. All had normal fasting blood sugar and no glucosuria. In this group no differences were observed with respect to the response to norepinephrine between those with normal and those with abnormal glucose tolerance. The dietary restrictions were stopped at least 3 days before the experiment.

\section{Infusion of norepinephrine}

The infusion experiments began at $8 \mathrm{a} . \mathrm{m}$. The last meal had been given $12-14 \mathrm{~h}$ earlier. Norepinephrine was diluted in $0.9 \%(\mathrm{w} / \mathrm{v})$ sodium chloride and infused intravenously at a rate of $0.08 \mu \mathrm{g} / \mathrm{kg}$, min with a constant infusion pump (Unita MI, Braun-Melsungen, normal concentration [18]. It can be reached under physiological circumstances during hard muscular work [38]. Norepinephrine was infused for $90 \mathrm{~min}$. Blood samples were obtained before the infusion (at zero-time), and every $15 \mathrm{~min}$ during the infusion. Blood for the determination of NEFA, free glycerol, IRI and ILA was allowed to clot for $2 \mathrm{~h}$ at room temperature, and the serum was frozen at $-20^{\circ} \mathrm{C}$ for later analysis. Blood for the determination of glucose and ketone bodies was immediately deproteinized with $\mathrm{HClO}_{4}$ and analyzed within $12 \mathrm{~h}$.

\section{Analytical methods}

The determination of blood glucose was carried out according to BERGMEYER and BERNT [3]; the determination of free glycerol according to WIELAND [42]; NEFA were measured according to DoLE and MEINERTZ $[10] ; \beta$-hydroxybutyrate and acetoacetate according to WILLIAMson, Meruanby and Krebs [43] as described previously [35]. The serum insulin-like activity (ILA) was determined by a modification (Wertzel, Sohaeg, Bodex, and Willms) [40] of the method of Martin, Rerrold and Dagenais [20]. The sera were diluted $1: 10$ and assayed in triplicates. The immunoreactive insulin in the serum (IRI) was measured by the method of Mrade and KITTGAARD [22] with the modifications described by MEIANI et al. [23]. Crystalline pig insulin (27 I U/mg) and ${ }^{131} \mathrm{I}$-insulin (spec. activity $150-190 \mathrm{mC} / \mathrm{mg}$ ) were generous gifts of the Farbwerke Hoechst, Frankfurt/Hoechst, Germany. Enzymes and coenzymes for the determination of glucose, glycerol, $\beta$-hydroxybutyrate and acetoacetate were obtained from C.F. Boehringer \& Soehne, Mannheim-Waldhof, Germany. All other chemicals were analytical grade from E. Merck, Darmstadt, Germany. Standard deviations $(s)$ were calculated as

Table 2. Fasting values at the beginning of the infusion of norepinephrine (zero-time). Mean values \pm s.d. The value indicated by an asterisk differ significantly from the control values

\begin{tabular}{|c|c|c|c|c|c|c|}
\hline Group & $\begin{array}{l}\text { Free } \\
\text { glycerol } \\
\text { umole/1 }\end{array}$ & $\begin{array}{l}\text { Nonesterified } \\
\text { fatty acids } \\
\text { meq/1 }\end{array}$ & $\begin{array}{l}\text { Total ketone } \\
\text { bodies } \\
\mu \text { mole/1. }\end{array}$ & $\begin{array}{l}\text { Glucose } \\
\mathrm{mg} / 100 \mathrm{ml}\end{array}$ & $\begin{array}{l}\text { Insulin-like } \\
\text { activity } \\
\mu \mathrm{U} / \mathrm{ml}\end{array}$ & $\begin{array}{l}\text { Immunoreac- } \\
\text { tive Insulin } \\
a \mathrm{U} / \mathrm{ml}\end{array}$ \\
\hline Control group & $\begin{array}{ll} & 76.9 \\
\pm & 34\end{array}$ & $\begin{array}{r}0.537 \\
\pm 0.182\end{array}$ & $\begin{array}{r}103 \\
+\quad 70\end{array}$ & $\begin{array}{r}78.1 \\
\pm \quad 11.8\end{array}$ & $\begin{array}{r}327 \\
+\quad 134\end{array}$ & $\begin{array}{r}12.8 \\
\pm \quad 2.1\end{array}$ \\
\hline $\begin{array}{l}\text { Tnsulin-dependent } \\
\text { diabetic group }\end{array}$ & $\begin{aligned} & 95.4 \\
+ & 46\end{aligned}$ & 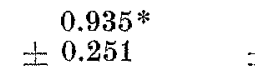 & $\begin{array}{l}\quad 856^{*} \\
+794\end{array}$ & $\begin{array}{l}254.8^{*} \\
\pm \quad 93.9\end{array}$ & $\begin{array}{r}367 \\
\pm \quad 97\end{array}$ & - \\
\hline $\begin{array}{l}\text { Obese diabetio } \\
\text { group }\end{array}$ & $\begin{aligned} & 87.2 \\
\pm & 24\end{aligned}$ & $\begin{array}{l}0.763^{*} \\
\pm 0.125\end{array}$ & $\begin{array}{c}158^{*} \\
+\quad 64\end{array}$ & $\begin{array}{c}163.6^{*} \\
\pm \quad 55.8\end{array}$ & $\begin{array}{r}495 \\
\pm 337\end{array}$ & $\begin{array}{l}17.4^{*} \\
\pm \quad 2.0\end{array}$ \\
\hline $\begin{array}{l}\text { Nonobese } \\
\text { diabetic group }\end{array}$ & $\begin{array}{r}86.3 \\
+48.5\end{array}$ & $\begin{array}{r}0.738 \\
+\quad 0.362\end{array}$ & $\begin{array}{r}232 \\
\pm 180\end{array}$ & $\begin{array}{l}170.7 * \\
+50\end{array}$ & $\begin{array}{r}285 \\
\pm 222\end{array}$ & - \\
\hline $\begin{array}{l}\text { Obese non- } \\
\text { diabetic group }\end{array}$ & $\begin{array}{r}93.7 \\
\pm 25.5\end{array}$ & $\begin{array}{l}0.792 * \\
\pm 0.212\end{array}$ & $\begin{array}{r}206 \\
+\quad 99\end{array}$ & $\begin{array}{r}78.9 \\
\pm \quad 13.4\end{array}$ & $\begin{array}{r}450 \\
+199\end{array}$ & $\begin{array}{l}23.9^{*} \\
\pm \quad 7.3\end{array}$ \\
\hline
\end{tabular}

Germany). This amount of norepinephrine should result in a steady state concentration of norepinephrine of $1.5-2.0 \mu \mathrm{g} / 1$ plasma after $5-7 \mathrm{~min}$ [38]. This concentration is about $3-5$ times higher than the
$S= \pm \sqrt{\frac{\sum(\bar{x}-x)^{2}}{(n-1)}} ; p$-values were calculated by the parameter-free U-test of MANN and WHITNEY [19]. 


\section{Results}

\section{Fasting values before norepinephrine-infusion}

The results are summarized in Table 2. The lowest values for NEFA and free glycerol occurred in the control group, and the highest in the insulin-dependent diabetic group. The blood concentrations of total ketone bodies (acetoacetate plus $\beta$-hydroxybutyrate) were significantly $(p<0.05)$ elevated in the insulindependent diabetics even before starting the infusion. Compared with the control group, slight elevations were noticed in the other groups. The correlation between NEFA and total ketone bodies $(r=0.47)$ in obese diabetics corresponded well with the value of $r=0.50$, described by WERK and KNOwLES [41] for unselected diabetics. The blood concentrations of

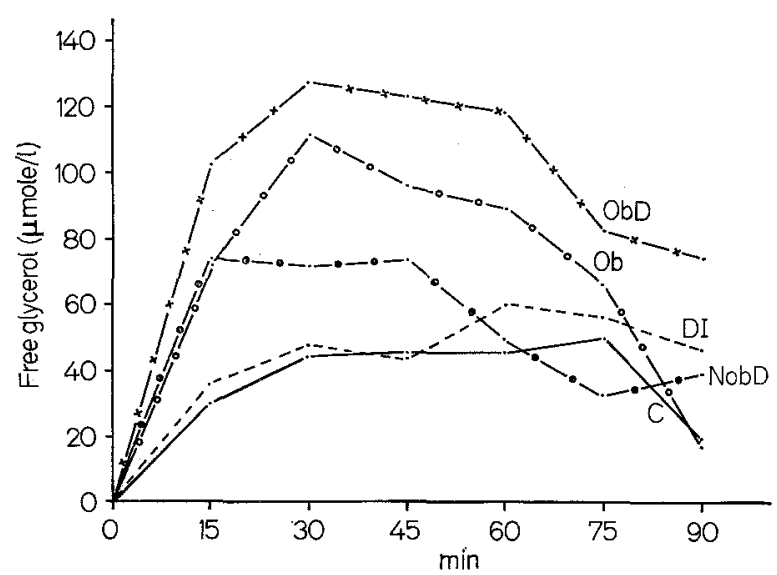

Fig. 1. Changes in the serum concentration of free glycerol during an intravenous infusion of norepinephrine, $0.08 \mu \mathrm{g} / \mathrm{kg} . \mathrm{min}$

The changes are related to the values at the beginning of the infusion, which were set as zero. $\mathrm{C}=$ Control group. $\mathrm{DI}=$ Insulin-dependent diabetic group. $\mathrm{ObD}=$ Obese diabetic group. $\mathrm{NobD}=$ Nonobese diabetic group. $\mathrm{Ob}=$ Obese nondiabetic group

glucose were similar in both nondiabetic groups; they were slightly elevated in obese and nonobese diabetics and significantly $(p<0.05)$ elevated in insulin-dependent diabetics. The ILA had not significantly changed in insulin-dependent diabetics compared with control subjects. In obese diabetic and nondiabetic subjects ILA and IRI had increased, which is in agreement with earlier reports $[5,6,8,12,16,26,44]$.

$$
\text { rate }
$$

Effect of norepinephrine on blood pressure and pulse

A depression of the pulse rate occurred in all groups. The mean value of all patients fell from $72 / \mathrm{min}$ to $62 / \mathrm{min}$ during the infusion, and rose to $74 / \mathrm{min}$ immediately after stopping the infusion. The increase of the blood pressure was positively correlated to the blood pressure at zero-time. Normotonic patients showed a rise from $125 / 80 \mathrm{mmHg}$ to $138 / 86 \mathrm{mmHg}(n=22)$, hypertensive persons from $151 / 94$ to $190 / 110 \mathrm{mmHg}$ $(n=15)$. These changes in blood pressure and pulse rate began immediately after the start of the infusion and remained unchanged throughout the whole experiment.

\section{Free glycerol and $N E F A$}

The increase in the serum concentrations of free glycerol and NEFA, calculated as difference from the concentrations at zero-time, is given in Fig. 1 and 2 . In spite of different fasting values, the increase in the concentrations of free glycerol and NEFA was in the same range in the 3 normal weight groups during the infusion. The 2 overweight groups (obese diabeties and obese nondiabetics) showed a significantly higher increase $(p<0.05)$ in the concentrations of both NEFA

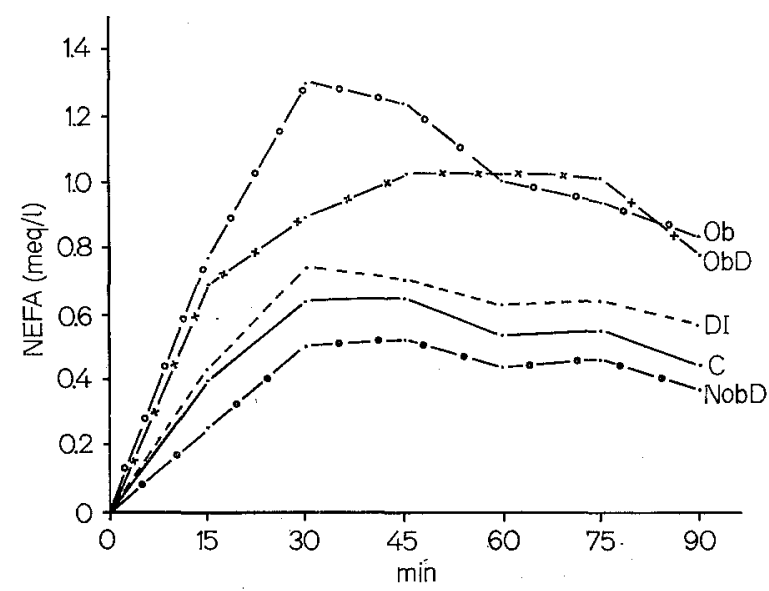

Fig. 2. Changes in the serum concentration of nonesterified fatty acids (NEFA) during an intravenous infusion of norepinephrine, $0.08 \mu \mathrm{g} / \mathrm{kg} \cdot \mathrm{min}$

The changes are related to the values at the beginning of the infusion, which were set as zero. $\mathrm{C}=$ Control group. $\mathrm{DI}=$ Insulin-dependent diabetic group. ObD = Obese diabetic group. NobD $=$ Nonobese diabetic group. $\mathrm{Ob}=$ Obese nondiabetic group

and glycerol, compared with the normal weight groups. This is in accordance with recent findings of BALASsE [1].

Not only the highest relative increase, but also the highest absolute concentrations of NEFA and glycerol occurred in the obese patients. Though the insulindependent diabetics started from a higher level, they did not reach the high absolute NEFA concentrations seen in the obese subjects (Table 3 ).

Therefore another group of obese patients was infused twice with norepinephrine, once according to the actual weight, once according to the theoretical normal weight (Table 4). Even with norepinephrine infused according to normal weight, the obese subjects showed a considerably higher increase in the concentrations of free glycerol and higher maximum values of NEFA than normal subjects.

The fasting values for free glycerol and NEFA were somewhat higher than in the obese group that was only 
once infused according to actual weight (Tables 3 and 4). This probably is due to the fact, that most of these patients were already on a restricted diet and thus had a higher basic rate of lipolysis. The maximum concen- very similar in both obese groups and was significantly higher $(p<0.02)$ than in the control group. The concentration of the total ketone bodies increased maximally in the insulin-dependent group. This increase

Table 3. Serum concentrations of nonesterified fath acids (NEF A) (meqll) during an intrawenows infusion of norepinephrine, 0.08 uglkg.min. Mean values $\pm s . d$.

\begin{tabular}{|c|c|c|c|c|c|c|c|}
\hline \multirow[t]{2}{*}{ Group } & \multicolumn{7}{|c|}{ Time (min) } \\
\hline & 0 & 15 & 30 & 45 & 60 & 75 & 90 \\
\hline Control group & $\begin{array}{r}0.537 \\
+\quad 0.182\end{array}$ & $\begin{array}{r}0.941 \\
+0.369\end{array}$ & $\begin{array}{r}1.179 \\
\pm \quad 0.352\end{array}$ & $\begin{array}{r}1.169 \\
\pm 0.334\end{array}$ & $\begin{array}{r}1.072 \\
\pm 0.241\end{array}$ & $\begin{array}{r}1.094 \\
\pm 0.276\end{array}$ & $\begin{array}{r}0.982 \\
\pm 0.221\end{array}$ \\
\hline $\begin{array}{l}\text { Insulin-dependent } \\
\text { diabetic group }\end{array}$ & $\begin{array}{r}0.935 \\
+0.251\end{array}$ & $\begin{array}{r}1.365 \\
+0.344\end{array}$ & $\begin{array}{r}1.744 \\
\pm 0.589\end{array}$ & $\begin{array}{r}1.641 \\
\pm 0.612\end{array}$ & $\begin{array}{r}1.566 \\
\pm 0.574\end{array}$ & $\begin{array}{r}1.577 \\
\pm 0.513\end{array}$ & $\begin{array}{r}1.513 \\
\pm 0.534\end{array}$ \\
\hline $\begin{array}{l}\text { Obese diabetic } \\
\text { group }\end{array}$ & $\begin{array}{r}0.763 \\
\pm 0.125\end{array}$ & $\begin{array}{r}1.454 \\
\pm 0.494\end{array}$ & $\begin{array}{r}1.664 \\
\pm 0.494\end{array}$ & $\begin{array}{r}1.821 \\
\pm 0.520\end{array}$ & $\begin{array}{r}1.861 \\
\pm 0.451\end{array}$ & $\begin{array}{r}1.776 \\
\pm 0.441\end{array}$ & $\begin{array}{r}1.543 \\
\pm \quad 0.350\end{array}$ \\
\hline $\begin{array}{l}\text { Nonobese diabetie } \\
\text { group }\end{array}$ & $\begin{array}{r}0.738 \\
+0.362\end{array}$ & $\begin{array}{r}1.001 \\
\pm 0.180\end{array}$ & $\begin{array}{r}1.250 \\
\pm 0.248\end{array}$ & $\begin{array}{r}1.259 \\
+0.114\end{array}$ & $\begin{array}{r}1.174 \\
\pm 0.080\end{array}$ & $\begin{array}{r}1.205 \\
\pm 0.132\end{array}$ & $\begin{array}{r}1.113 \\
\pm 0.245\end{array}$ \\
\hline $\begin{array}{l}\text { Obese nondiabetic } \\
\text { group }\end{array}$ & $\begin{array}{r}0.792 \\
+0.212\end{array}$ & $\begin{array}{r}1.504 \\
+\quad 0.648\end{array}$ & $\begin{array}{r}2.001 \\
\pm 0.471\end{array}$ & $\begin{array}{r}1.969 \\
+0.486\end{array}$ & $\begin{array}{r}1.861 \\
+0.439\end{array}$ & $\begin{array}{r}1.729 \\
+0.406\end{array}$ & $\begin{array}{r}1.681 \\
+\quad 0.372\end{array}$ \\
\hline
\end{tabular}

Table 4. Serum concentrations of NEF A and free glycerol and blood concentration of total ketone bodies in 10 obese subjects during infusion of norepinephrine. All patients were infused wice with norepinephrine: once they received 0.08 uglkg.min of actual weight, and once $0.08 \mathrm{ug} / \mathrm{kg}$.min of theoretical normal weight. For definition of normal weight see "Methods". The infusion lasted from 0 to $90 \mathrm{~min}$

\begin{tabular}{|c|c|c|c|c|c|c|c|c|c|c|}
\hline Time $(\mathrm{min})$ & & 0 & 15 & 30 & 45 & 60 & 75 & 90 & 105 & 120 \\
\hline $\begin{array}{l}\text { NEFA } \\
(m e q / 1)\end{array}$ & $\begin{array}{l}\text { actual w. } \\
\text { normal w. }\end{array}$ & $\begin{array}{l}1.129 \\
1.128\end{array}$ & $\begin{array}{l}1.710 \\
1.515\end{array}$ & $\begin{array}{l}1.915 \\
1.615\end{array}$ & $\begin{array}{l}1.922 \\
1.627\end{array}$ & $\begin{array}{l}1.814 \\
1.502\end{array}$ & $\begin{array}{l}1.681 \\
1.391\end{array}$ & $\begin{array}{l}1.590 \\
1.315\end{array}$ & $\begin{array}{l}1.327 \\
1.152\end{array}$ & $\begin{array}{l}1.062 \\
0.842\end{array}$ \\
\hline \multirow{2}{*}{$\begin{array}{l}\text { Free } \\
\text { glycerol } \\
(\text { umole } /)\end{array}$} & actual w. & 107 & 278 & 262 & 242 & 192 & 178 & 121 & 88 & 62 \\
\hline & normal $\mathrm{w}$. & 122 & 244 & 232 & 162 & 127 & 156 & 102 & 72 & 60 \\
\hline \multirow{2}{*}{$\begin{array}{l}\text { Total ketone } \\
\text { bodies } \\
(\text { (umole/1) }\end{array}$} & actual $w$. & 394 & 666 & 1013 & 1221 & 1388 & 1507 & 1741 & 1607 & 1410 \\
\hline & normal w. & 466 & 703 & 952 & 1178 & 1279 & 1368 & 1428 & 1433 & 1299 \\
\hline
\end{tabular}

trations of NEFA reached during the infusion of norepinephrine according to actual weight, showed no difference between the two groups of obese patients. In all groups a decline in the concentrations of free glycerol and NEEA became visible already during the infusion of norepinephrine. This decline started between the 30 th and 60 th $\mathrm{min}$, whereas the norepinephrine effects on the circulatory system remained nnchanged.

When blood was taken $30 \mathrm{~min}$ after stopping the infusion, the concentrations of NEFA and free glycerol had fallen to or below the starting value (Table 4).

The fasting value of the molar ratio NEFA/free glycerol did not significantly differ among the 5 groups studied (Table 5). During the norepinephrine-infusion, we observed an increase of this ratio in all groups. The highest increase, up to 15 , occurred in the obese diabetics.

\section{Total ketone bodies}

In all groups a distinct increase was already measurable after $15 \mathrm{~min}$ (Fig. 3). The increase was
Table 5. Molar ratio NEE Alfree glycerol during an miravenous inftusion of norepinephrine, $0.08 \mathrm{Hg} / \mathrm{kg} . \mathrm{min}$ for 90 minutes

\begin{tabular}{|c|c|c|c|c|}
\hline \multirow[t]{2}{*}{ Group } & \multicolumn{4}{|c|}{ Time $(\min )$} \\
\hline & 0 & 30 & 60 & 90 \\
\hline Control group & $\begin{array}{r}8.0 \\
+\quad 3.2\end{array}$ & $\begin{array}{r}9,6 \\
\pm 2.7\end{array}$ & $\begin{array}{r}9.3 \\
\pm \quad 2.7\end{array}$ & $\begin{array}{r}11.3 \\
\pm \quad 6.1\end{array}$ \\
\hline $\begin{array}{l}\text { Tnsulin-dependent } \\
\text { diabetic group }\end{array}$ & $\begin{array}{r}12.0 \\
\pm \quad 7.3\end{array}$ & $\begin{array}{r}13.9 \\
\pm \quad 5.1\end{array}$ & $\begin{array}{r}11.9 \\
\pm \quad 3.3\end{array}$ & $\begin{array}{r}14.1 \\
+\quad 6.7\end{array}$ \\
\hline $\begin{array}{l}\text { Obese diabetic } \\
\text { group }\end{array}$ & $\begin{array}{r}9.6 \\
\pm \quad 3.8\end{array}$ & $\begin{array}{r}7.9 \\
+1.8\end{array}$ & $\begin{array}{r}9.5 \\
+\quad 2.5\end{array}$ & $\begin{array}{r}11.0 \\
\pm \quad 4.1\end{array}$ \\
\hline $\begin{array}{l}\text { Nonobese diabetic } \\
\text { group }\end{array}$ & $\begin{array}{r}6.6 \\
+\quad 1.4\end{array}$ & $\begin{array}{r}8.9 \\
+\quad 2.8\end{array}$ & $\begin{array}{r}9.4 \\
\pm \quad 2.8\end{array}$ & $\begin{array}{r}9.3 \\
\pm \quad 2.7\end{array}$ \\
\hline $\begin{array}{l}\text { Obese nondiabetic } \\
\text { group }\end{array}$ & $\begin{array}{r}8.1 \\
\pm \quad 2.0\end{array}$ & $\begin{array}{r}10.4 \\
\pm \quad 3.8\end{array}$ & $\begin{array}{r}10.7 \\
\pm \quad 2.4\end{array}$ & $\begin{array}{r}14.9 \\
\pm \quad 6.3\end{array}$ \\
\hline
\end{tabular}

was independent of the concentration at zero-time, and rather similar in all individuals of this group. In conw trast to the changes in the concentrations of NEFA and free glycerol, the concentration of ketone bodies 
rose during the whole experiment, with some flattening of the curve after about $60 \mathrm{~min}$ in the nondiabetic and in the obese and nonobese diabetic group.

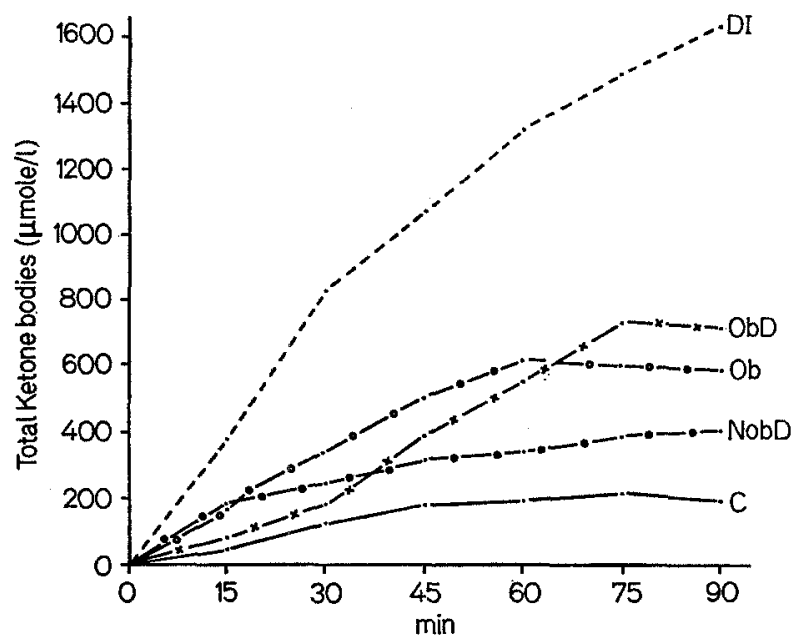

Fig. 3. Changes in the blood concentration of total ketone bodies ( $\beta$-hydroxybutyrate and acetoacetate) during an intravenous infusion of norepinephrine, $0.08 \mu \mathrm{g} / \mathrm{kg} . \mathrm{min}$. The changes are related to the values at the beginning of the infusion, which were set as zero. $\mathrm{C}=\mathrm{Control}$ group. $\mathrm{DI}=$ Insulin-dependent diabetic group. $\mathrm{ObD}=$ Obese diabetic group. NobD $=$ Nonobese diabetic group. $\mathrm{Ob}=$ Obese nondiabetic group.

\section{$\beta$-Hydroxybutyrate/acetoacetate ratio}

The $\beta$-hydroxybutyrate/acetoacetate ratio increased in all groups during the infusion of norepinephrine (Table 6). In all groups, this increase exceeded the increase in the control group. The insulin-dependent diabetics showed the highest ratio at zero-time, and the greatest increase during the infusion of norepinephrine. during the infusion of norepinephrine, but a general correlation between the fasting blood glucose values and the increase in ketone body concentrations could not be found.

Compared with the control group, higher fasting concentrations of NEFA in the other groups were associated with higher concentrations of blood ketone bodies. A comparison of the maximum increases in both parameters on an equimolar basis reveals, that the insulin-dependent diabetics did not only reach the highest absolute concentrations of ketone bodies, but showed also the highest increase in the concentration of ketone bodies in relation to the rise in the concentration of NEFA. The ratio NEFA-increase (meq/I)/ ketone body increase (mmole/l) was $1: 2.08$ in insulindependent diabetios compared with $1: 0.27$ in the control group, $1: 0.47$ in obese and nonobese diabetics and $1: 0.52$ in obese nondiabetics.

One might argue that the NEFA concentration in the insulin-dependent diabetics was already highest at the beginning of the experiment, and thus an additional increase in the NEFA concentration would lead to a more pronounced increase in ketone body formation in this group. We therefore compared the planimetric areas limited by the curves of the absolute concentrations of NEFA and of the total ketone bodies. The corresponding ratios were $1: 1.22$ in the insulindependent group, 1:0.23 in the control group. The other groups ranged between $1: 0.27$ and $1: 0.45$. Thus insulin-dependent diabetics showed the greatest increase of blood ketone bodies in relation to the serum concentrations of NEFA. This increase exceeded by far the increase seen in obese patients (nondiabetic and diabetic) in spite of the fact that the obese patients reached significantly higher absolute concentrations of NEFA (Table 3).

Table 6. Molar ratio $\beta$-hydroxybutyrate/acetoacetate during an intravenous infusion of norepinephrine, $0.08 \mu g / k g . m i n$ for 90 min. Mean values \pm s.d. The values indicated by an asterist differ significantly from the control values

\begin{tabular}{|c|c|c|c|c|c|c|c|}
\hline \multirow[t]{2}{*}{ Group } & \multicolumn{7}{|c|}{ Time (min) } \\
\hline & 0 & 15 & 30 & 45 & 60 & 75 & 90 \\
\hline Control group & $\begin{array}{ll} & 1.66 \\
\pm & 1.2\end{array}$ & $\begin{array}{ll} & 1.94 \\
\pm & 1.8\end{array}$ & $\begin{array}{r}2.21 \\
\pm 1.57\end{array}$ & 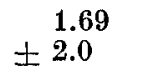 & $\begin{array}{r}2.21 \\
\pm 1.47\end{array}$ & $\begin{array}{r}2.32 \\
\pm 1.57\end{array}$ & $\begin{aligned} & 2.26 \\
\pm & 1.3\end{aligned}$ \\
\hline $\begin{array}{l}\text { Insulin-dependent } \\
\text { diabetic group }\end{array}$ & $\begin{array}{l}3.51 * \\
\pm 0.8\end{array}$ & $\begin{array}{ll} & 4.15^{*} \\
\pm & 1.2\end{array}$ & $\begin{array}{ll} & 5.07 * \\
\pm & 1.0\end{array}$ & $\begin{aligned} & 4.86^{*} \\
\pm & 1.16\end{aligned}$ & $\begin{aligned} & 4.57 * \\
\pm & 1.16\end{aligned}$ & $\begin{array}{ll} & 4.68^{*} \\
\pm & 1.5\end{array}$ & $\begin{aligned} & 4.91 * \\
\pm & 1.5\end{aligned}$ \\
\hline $\begin{array}{l}\text { Obese diabetic } \\
\text { group }\end{array}$ & $\begin{array}{ll} & 2.64 \\
\pm & 1.0\end{array}$ & $\begin{array}{r}2.94 \\
\pm 1.47\end{array}$ & $\begin{array}{ll} & 2.67^{*} \\
\pm & 1.2\end{array}$ & $\begin{aligned} & 3.91^{*} \\
\pm & 0.7\end{aligned}$ & 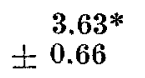 & $\begin{aligned} & 3.89^{*} \\
\pm & 0.8\end{aligned}$ & $\begin{aligned} & 3.96 * \\
\pm & 1.1\end{aligned}$ \\
\hline $\begin{array}{l}\text { Nonobese diabetic } \\
\text { group }\end{array}$ & $\begin{array}{l}3.4^{*} \\
\pm 1.5\end{array}$ & $\begin{array}{ll} & 3.72 \\
\pm & 1.0\end{array}$ & $\begin{array}{l}3.66 \\
\pm 0.7\end{array}$ & $\begin{array}{ll} & 3.52 \\
\pm & 0.9\end{array}$ & $\begin{array}{r}3.62 \\
\pm 0.97\end{array}$ & $\begin{array}{l}3.48 \\
\pm \\
0.7\end{array}$ & $\begin{array}{r}3.55 \\
\pm 0.76\end{array}$ \\
\hline $\begin{array}{l}\text { Obese nondiabetic } \\
\text { group }\end{array}$ & $\begin{array}{l}3.06^{*} \\
\pm \\
0.7\end{array}$ & $\begin{aligned} & 2.91 \\
\pm & 0.7\end{aligned}$ & 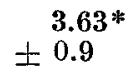 & 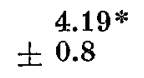 & $\begin{array}{l}3.72^{*} \\
\pm 0.8\end{array}$ & $\begin{aligned} & 4.20^{*} \\
\pm & 1.4\end{aligned}$ & $\begin{aligned} & 3.81 * \\
\pm & 1.5\end{aligned}$ \\
\hline
\end{tabular}

Relationship between the concentrations of blood glucose, NEFA and ketone bodies

The insulin-dependent diabetic group showed the highest fasting blood sugar concentrations and a maximal increase in the concentration of ketone bodies

\section{Glucose}

The concentration of blood glucose rose markedly in the insulin-dependent diabetics $(p<0.05$ versus controls), but only slightly in the other groups without significant differences between the groups (Fig. 4). 


\section{Serum ILA and serum IRI}

The ILA rose in all groups with a maximum value at 60 minutes (Fig. 5). The highest increase occurred in the obese diabetic group, the lowest in the nonobese

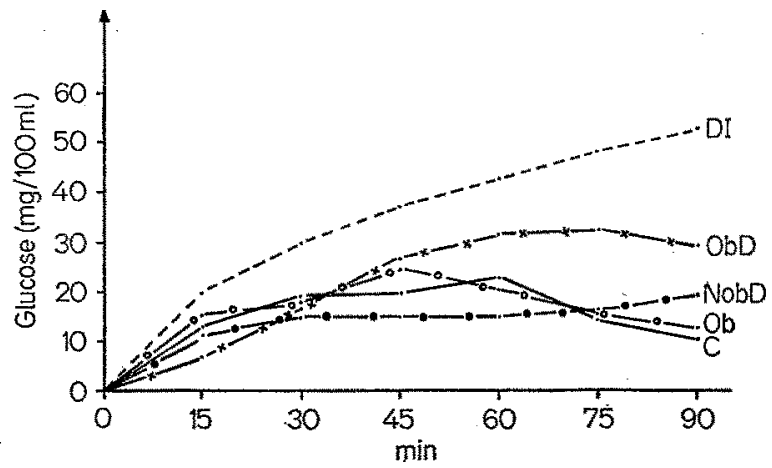

Fig. 4. Changes in the blood concentration of glucose during an intravenous infusion of norepinephrine, $0.08 \mu \mathrm{g} / \mathrm{kg}$.min

The changes are related to the values at the beginning of the infusion, which were set as zero. $\mathrm{C}=\mathrm{Control}$ group. DI $=$ Insulin-dependent diabetic group. $\mathrm{ObD}=$ Obese diabetic group. NobD $=$ Nonobese diabetic group. $\mathrm{Ob}=$ Obese nondiabetic group

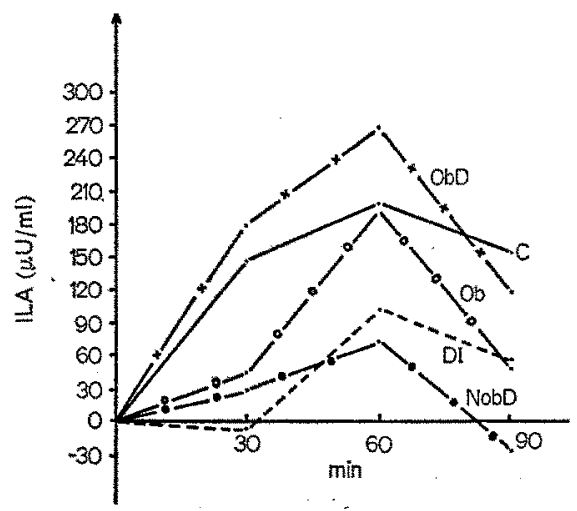

Fig. 5. Changes in the serum concentration of insulin-like activity (IIA) during an intravenous infusion of norepinephrine, $0.08 \mu \mathrm{g} / \mathrm{kg} \cdot \mathrm{min}$

The changes are related to the values at the beginning of the infusion, which were set as zero. $\mathrm{C}=$ Control group. DI $=$ Insulin-dependent diabetic group. $\mathrm{ObD}=$ Obese diabetic group. NobD $=$ Nonobese diabetic group. $\mathrm{Ob}=$ Obese nondiabetic group diabetic group. From the 60th to the 90th min, IrA decreased, thus paralleling the decline in lipolysis already described. The IRI did not change significantly in the control group, but increased significantly in the obese diabetic group ( $p<0.05$ ), and even more pronounced in the obese nondiabetic group after $90 \mathrm{~min}$ $(p<0.025)$ (Table 7). The different time course in the serum concentrations of ILA and. IRI again demonstrates that these two parameters represent different biological materials.

\section{Discussion}

\section{Differences in lipolysis}

The higher rate of lipolysis in obese subjects probably does not result from an enhanced sensitivity to norepinephrine, but from the fact that in our experiments norepinephrine was given per $\mathrm{kg}$ body weight. The greater increase in NEFA and free glycerol observed in the overweight subjects may be due to their greater mass of adipose tissue. This greater response to norepinephrine was found in obese persons even when they received norepinephrine in amounts calculated from their normal instead from their actual weight (Table 4).

\section{NEEA/free glycerol ratio}

JAtris [15] found a ratio of 10 in control subjects and a significantly lower ratio of 7.3 in obese nondiabetics. An increased ratio as a result of catecholamine stimulation was also seen by MüLcer and Evars [24]. The higher ratio means that either more NEFA molecules than glycerol molecules are released from adipose tissue or that glycerol is more quickly removed from the plasma than NEFA, or a combination of both. The first explanation seems to be possible; an imcomplete hydrolysis of triglycerides has indeed been described by WADsTröm [39] and by Scow et al. [31], and recently GoRIN and SHAFRIR [11] have brought evidence for a rate-limiting role of monoglyceride lipase in intact adipose tissue. But to us it seems more probable that the high NEFA/glycerol ratio reflects mainly

Table 7. Serum immunoreactive insulin (IRI) during an intravenous infusion of norepinephrine, $0.08 \mu \mathrm{g} / \mathrm{kg} . \mathrm{min}$ for 90 min. Mean values \pm s.d.

\begin{tabular}{llllll}
\hline Group & Time $(\mathrm{min})$ & & & \\
\cline { 2 - 5 } & 0 & 30 & 60 & 90 & $p^{\mathrm{a}}$ \\
\hline $\begin{array}{l}\text { Control } \\
(n=7)\end{array}$ & $12.8 \pm 2.1$ & $13.8 \pm 2.0$ & $12.9 \pm 1.7$ & $14.0 \pm 2.0$ & n.s. \\
$\begin{array}{l}\text { Obese diabetics } \\
(n=6)\end{array}$ & $17.4 \pm 2.0$ & $17.9 \pm 1.9$ & $17.1 \pm 2.6$ & $21.1 \pm 3.4$ & $<0.05$ \\
$\begin{array}{l}\text { Obese nondiabetics } \\
(n=9)\end{array}$ & $23.9 \pm 7.3$ & $26.2 \pm 5.1$ & $29.8 \pm 7.9$ & $36.1 \pm 11.9$ & $<0.025$ \\
\hline
\end{tabular}

The $p$-values wore calculated for the difference between the mean values at zero-time and after 90 min. 
a shorter half life of serum glycerol $[29,25]$ compared with that of serum NEFA [14].

Decrease of NEFA and free glycerol towards the end of the infusion

A decrease of NEFA and glycerol already during the infusion of catecholamines was reported by DELORMIE [9] in dogs, BLACKARD and OMORI [4] and SANDHOFER et al. [28] in man, but could not be found in dogs by Carrson [7].

Since the concentrations of NEFA and free glycerol decreased simultaneously, one can assume this decrease to be the result of a diminished lipolysis.

Inhibition of lipolysis by insulin may be partly responsible in the obese nondiabetics, who showed a coincidence of a marked fall in glycerol and a rise in IRI at $60 \mathrm{~min}$ and $90 \mathrm{~min}$. But it is unlikely that insulin is of any importance in the insulin-dependent diabetics, who showed about the same decline of NEFA and glycerol as normal subjects. Therefore the main reason seems to be the feedback inhibition of lipolysis by an increasing concentration of NEFA within the adipose tissue cell (RODBELI [27], BALLY et al. [2]).

\section{Relationship between the concentrations of NEFA and ketone bodies}

The higher rise in the concentration of ketone bodies in relation to the increase in the concentration of NEFA in insulin-dependent diabetics is not compatible with the findings obtained in experiments with isolated, perfused livers of normal and diabetic rats $[30,35,36]$. It can be due to either an enhanced oxidation of fatty acids by the liver or a decreased peripheral utilization of ketone bodies in human diabetics. The greater increase of the $\beta$-hydroxybutyrate/acetoacetate ratio in the blood of insulin-dependent diabetics during infusion of norepinephrine could point to an increased oxidation of fatty acids. Recent balance studies of MaYes and FeLTS [21] have brought some evidence that the increased oxidation of fatty acids in the diabetic liver might result mainly from an impaired esterification of fatty acids, thus allowing relatively more fatty acids to be oxidized. This does not exelude the possibility that in insulin-dependent diabetics an additional defect in peripheral ketone body utilization contributes to the greater increase in the concentration of ketone bodies. The importance of the utilization of glucose for the peripheral utilization of ketone bodies has been demonstrated recently (Scow and Crmerniok [30], Sörtag, Garlepp, CReutzFeldt [33]). There is sufficient evidence that this carbohydrate-dependent utilization of ketone bodies occurs in the adipose tissue (Böring [34], Hanson and Zrportin [13], Söting,

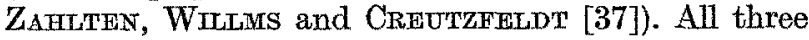
normal weight groups showed about the same increase in the serum concentration of NEFA, whereas the concentrations of ketone bodies rose according to the severity of diabetes mellitus. Thus the degree of ketosis in normal weight diabetics seems to be determined mainly by the factor "insulin deficiency".

In the overweight groups, however, the concentrations of NEFA increased significantly more than in the normal weight groups; but there was no significant difference between diabetios and nondiabetics in the increase of ketone bodies. Apparently, in insulinindependent, overweight diabetics, abnormalities in lipid metabolism have to be related mainly to the factor "obesity".

Acknowledgements. The authors thank Dr. H. FrERICHs, Göttingen, for a gift of insulin antiserum, and Drs. F.H. Sонмrdт, Boehringer, R. MüLLeR, Farbwerlze Hoechst and G. MrokaEL, Chemie Grünenthal for their support.

\section{References}

1. BAIASSE, E.: Influence of norepinephrine, growth hormone and fasting on FFA-mobilization and glucose metabolism in lean and obese subjects. Diabetologia 4 , 20-25 (1968).

2. Batuy, P.R., H. Kappeler, E.R. Froesor, and A. LABHART: Effect of glucose in spontaneous limitation of lipolysis in isolated adipose tissue: a potential regulatory mechanism. Ann. N. Y. Acad. Sci. 131, 143$156(1965)$.

3. Bergmeyer, H.U., u. E. Burnt: Gluçose oxidase Methode. In "Methoden der enzymatischen Analyse", herausgegeben von H. U. BERGMEYER, S. 123. Weinheim: Verlag Chemie, 1962.

4. Blackard, W.G., and Y. OMonr: Blood ketone response to norepinephrine-induced FFA-elevation in diabetes. Diabetes 13, 518-526 (1964).

5. Bornstein, J., and R.D. Lawrenow: Plasma insulin in human diabetes mellitus. Brit. Med. J. 1951 II, $1541-1544$.

6. Botmermann, P., K. Schwarz a. K. Kopertz: Utber das Verhalten der ILA im Serum bei der Fettsucht Dtsch, med. Wschr, 90, 917-921 (1967).

7. Cartison, L.A., S.O. LILJHDAHI, and C. WIRZTIN: Blood and tissue changes in the dog during and after excessive FFA mobilization. Acta med. scand. 178, $81-102(1965)$.

8. Dawker, H.: ILA im menschlichen Serum. Acta endocr. (Kbh.) 42, 437-452 (1963).

9. Delorme, M.: Hemmung der Insulinwirkung durch die freien Fettsäuren beim Hund, Klin. Wschr. 43, $729-732(1965)$.

10. Doue, V.P., and H. Mernertz: Microdetermination of long-chain fatty acids. J. biol. Chem. 235, 2595$2599(1960)$.

11. Gorm, E., and E. Shafrer: Activation and inhibition of tri and monoglyceride lipases in adipose tissue. Biochim. biophys. Acta 137, 189-191 (1967).

12. Grodsky, G.M., J.H. KaRam, F.C. Pavaltos, and P.H. ForshaM: Reduction by Phenformin of excessive insulin levels after glucose loading in obese and diabetic subjects. Metabolism 12, 278-286 (1963).

13. HANSON, R.W., and Z.Z. ZIPORIN : Factors influencing the utilization of ketone bodies by mouse adipose tissue. J. Lipid Res. 7, 56-61 (1966).

14. Haves, R.J., and D.S. Frendmrokson: The metabolism of ehylomicra. I. The removal palmitie acid-1-C 14 labeled chylomicra from dog plasma. J. clin. Invest. 35, 1025-1032 (1956).

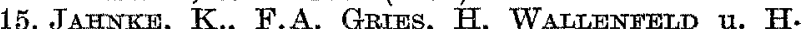
Schulte: Verhalten von Metaboliten des Fettstoffweehsels im Serum adipöser und nicht-adipöser Per- 
sonen unter Grundumsatzbedingungen. Klin. Wschr. 42, 1016-1020 (1964).

16. Karam, J.H., G.M. Grodsky, and P.H. Forsham: Excessive insulin response to glucose in obese subjects as measured by immuno-chemical assay. Diabetes 12, $197-204$ (1963).

17. KAYE, R., and M.H. Davidson: The response of blood glucose and plasma non-esterified fatty acids to fasting and epinephrine infusion in infants and children. $J$. Pediat. 59, 836-847 (1959).

18. KLENsCH, H.: Der basale Noradrenalinspiegel im peripheren venösen Blut des Menschen. Pflügers Arch. ges. Physiol. 290, 218-224 (1966).

19. MANN, H.B., and D.R. WHITNEY: Ann. math. statist. 18, 50-60 (1947) - zitiert nach WEBER, E. : Grundriß der biologischen Statistik. Jena: VEB Gustav Fischex Verlag 1964.

20. Martin, D.F., A.E. Rerold, and Y.M. Daghnals: An assay for insulin like activity using rat adipose tissue. Lancet $1958 \mathrm{I}, 76-77$.

21. MAYES, P.K., and J.M. FeLTS: Regulation of fat metabolism in the liver. Nature 215, 716-718 (1967).

22. Mrade, R.C., and H.M. Kurtgaato: A simplified method for immunoassay of human serum insulin. J. nucl. Med. 3, 407-416 (1962).

23. Melant, F., H. Ditschuneit, K.M. Bartelt, H. Friedrioh u. E. F. Pferfyerr : Ưber die radioimmunologische Bestimmung von Insulin im Blut. Klin. Wschr. 43, $1000-1007$ (1965).

24. MÜLrER, P.S., and W.H. Evans: Response of plasma glycerol concentrations to epinephrine, norepinephrine, glucose, insulin, and prolonged fasting in man. J. Lab. clin. Med. 61, 953-961 (1963).

25. Pelronen, R., E.A. NmkkTü̈, and M Kekki: Metabolism of glycerol in diabetes mellitus. Diabetologia 3, $1-8(1967)$.

26. RabinowiTz, D., and K.L. ZreRLER: Forearm metabolism in obesity and its response to intraarterial insulin. Characterization of insulin resistance and evidence for adaptive hyperinsulinism. J. clin. Invest. 41, 2173-2181 (1962).

27. RodBenc, M.: Modulation of lipolysis in adipose tissue by fatty acid concentration in fat cell. Ann. N.Y. Acad. Sci. 131, 302-314 (1965).

28. Sand hofer, F., S. SaIler, F. Dienstu u. H. BraunSTEINER: Über den Einfluß von Katecholaminen auf die Umsatzrate der freien Fettsäuren und die Bildung von Plasmatriglyceriden. Klin. Wschr. 45, 486-492 (1967).

29. Schwarz, K., P. Botterminan, G. Claussen, K. KoPETz u. K.P. ExMer: Untersuchungen über die Resorption und die biologische Halbwertzeit von Glycerin beim Menschen. Klin. Wschr. 33, 1183-1187 (1962).

30. Scow, R.O., and S.S. CHERNICK: Hormonal control of protein and fat metabolism in the pancreatectomized rat. Recent. Progr. Hormone Res. 16, 497-541 (1960).
31. 一, F.A. StrRicker, T.Y. PICK, and T.R. CLARY: Effect of ACTH on FFA release and diglyceride content in perfused rat adipose tissue. Ann. N.Y. Acad. Sci. 131, 288-301 (1965).

32. Society of Actuaries (edit.), Build and Blood Pressure Study, Vol. 1. Chicago: 1959, cit. from Basel: Documenta Geigy Wissenschaftliche Tabellen 1960.

33. SötingG, H.D., H.J. GarlepP u. W. CReutzateldt: Wirkung von Insulin und Glucose auf die Ketonkörperaufnahme totaleviscerierter normaler, hungernder und alloxandiabetischer Ratten. Biochim. biophys. Acta 100, 530-543 (1965).

34. - Zur Autonomie des Ketonkörperstoffwechsels. Verh. dtsch. Ges. inn. Med. 72, 792-799 (1966).

35. -, R. Kattermann, H. SchmidT, and P. KNEER: The redoxstate of $\mathrm{NAD}^{+} / \mathrm{NADH}$-systems in rat liver during ketosis and the so-called "TriosephosphateBlock". Biochim. biophys. Acta 115, 1-14 (1966)

36. - R. Koschel, W. Drägert, P. KNeER u. W. CReutzFeldt: Die Wirkung von Insulin auf den Stoffwechsel der isolierten perfundierten Leber normaler und alloxan-diabetischer Ratten. Teil I. Diabetologia 2, 20-31 (1966).

37. - R. Zahlten, B. Willms, and W. Crectzfeidit Utilization of ketone bodies by adipose tissue and its regulation by carbohydrate metabolism. Biochim. biophys. Acta, in press.

38. VENDSALU, A.: Studies on adrenaline and noradrenaline in human plasma. Acta physiol. scand. 43, suppl. 173 (1960).

39. WADSTRöM, L.B.: Lipolytic effect of the injection of adrenaline on fat depots. Nature 179, 259-260 (1957).

40. Wirtzer, G., W. Schate, G. Bodmen u. B. Wruems: Einfluß der Photooxydation auf Histidingehalt und Aktivität von Insulin. Justus Liebigs Ann. Chem. 689, $248-258$ (1965).

41. WERK, E.E., and H.C. KNowles: The blood ketone and plasma free fatty acid concentration in diabetic and normal subjects. Diabetes 10, 22-32 (1961).

42. WIELAND, O.: Eine enzymatische Methode zur Bestimmung von Glycerin. Biochem. Z. 329, 313-319 (1957).

43. Witutamson, D.H., J. Mellanby, and H.A. KreBs : Enzymatic determination of $\mathrm{D}(-) \beta$-hydroxybutyric acid and acetoacetic acid in blood. Biochem. J. 82, 90-96 (1962)

44. YALOw, R.S., and S.A. Berson: Immunoassay of endogenous plasma insulin in man. J. clin. Invest. 39, $1157-1175(1960)$.

Dr. med. BEREND WIIIIMS

Priv. Doz. Dr. med. Hars-Dieter SölnNG 34 Göttingen

Med. Univ. Klinik

Humboldtallee 1 